\title{
PRODUCTIVITY IMPROVEMENT OF ONION (Allium cepa, L. ) USING NATURAL FERTILIZERS OF PHOSPHORUS AND POTASSIUM UNDER SOUTH SINAI, CONDITIONS
}

\author{
(Received: 23.11. 2010)
}

\author{
By \\ I. M. El- Hifny and Sh. B. D.Yousef \\ Desert Research Center, El-Matareya,Cairo, Egypt
}

\begin{abstract}
Two field experiments were carried out at Ras Suder Experimental Station in South Sinai Governorate during 2006/2007 and 2007/2008 seasons to study the effect of natural fertilizers of phosphorus and potassium and the combination between them (rock phosphate $22 \% \mathrm{P}_{2} \mathrm{O}_{5}$ and feldspar $10 \% \mathrm{~K}_{2} \mathrm{O}$ ) at the rates of $0,30,45 \mathrm{P}_{2} \mathrm{O}_{5}$ units/ fed. and $0,48,96 \mathrm{~K}_{2} \mathrm{O}$ units/ fed., respectively. Also, NPK mineral fertilizers were used by the recommended dose as $60 \mathrm{~N}, 30 \mathrm{P}_{2} \mathrm{O}_{5}$ and $48 \mathrm{~K}_{2} \mathrm{O}$ units/fed. on growth yield and its components as well as chemical compositions of onion. Drip irrigation system and saline water (about $3700 \mathrm{ppm}$ ) was used, the soil was saline and highly calcareous $\left(49.5 \% \mathrm{CaCO}_{3}\right)$.

The obtained results revealed that growth characters i.e., plant length, number of leaves/ plant, plant fresh weight of leaves and bulb, also, dry matter of bulb and bulb diameter gave significantly the highest values compared with the control treatment (mineral fertilizers) or natural combination fertilizers treatment ( $48 \mathrm{P}_{2} \mathrm{O}_{5}$ rock phosphate plus $96 \mathrm{~K}_{2} \mathrm{O}$ feldspar units/ fed.). Also, the total yield, fresh weight of the bulb and bulb diameter were significantly the highest with the same natural treatment compared to other treatments.

TSS, N, $\mathrm{K}$ and $\mathrm{SO}_{4}$ showed the highest content in onion bulbs with the preveous natural treatment or the control treatment, while the lowest and best figures of $\mathrm{Na}$ and $\mathrm{Cl}$ content were found with natural fertilizers at rates of $45 \mathrm{P}_{2} \mathrm{O}_{5}$ plus $48 \mathrm{~K}_{2} \mathrm{O}$ units/ fed.
\end{abstract}

Key words : Allium cepa, natural fertilizers, phosphorus, potassium, productivity improvement.

\section{INTRODUCTION}

Onion is one of the popular vegetables in Egypt. Increasing productivity of onion is an important target by the growers for local and foreign consumption. The reclaimed calcareous and saline soils are considered valuable future expansion. Attention should be taken with respect to natural nutritional status to reduce contamination and produce healthy plants. Taking in consideration the fact that chemical fertilizers are expensive in Egypt.

Phosphorus is an essential nutritional element, which plays a role in regulation of many physiological functions in plant which in turn affect growth and yield. Nikolay Vassilev et al. (1996) reported that organic phosphorus is mineralized and immobilized by microbe activities. Phosphorus is a major building block of DNA molecules (Pant and Reddy, 2003). Hinsinger (2001) reported that the two forms of phosphorus in the soil are organic and inorganic. Organic phosphorus is the most stable form in the soil. Shaheen et al. (2007) studied the influence of using rock phosphate and calcium superphosphate at 3 rates for onion. Increasing the rates up to $48 \mathrm{P}_{2} \mathrm{O}_{5}$ units /fed. plant growth recorded the highest peaks. Super-phosphate form gained the heaviest tonnage of bulb yield. On the contrary, rock phosphate increased mineral content in the bulbs than super phosphate.

It is known that potassium is one of the most important elements in plant nutrition. Potassium improves drought resistance, the plant needs it in a large quantity to assimilate and improve growth and yield . (Marschner, 1995). The main source of $\mathrm{K}$ for plant comes from mineral and organic- $\mathrm{K}$ source. K- feldspar is one of the most important $\mathrm{K}$ minerals (Straaten, 2002). Many investigators studied the response of onion to the potassium sources and rates. They found that with increasing potassium application rate, vegetative growth and mineral uptake were increased (Rizk, 2001; Ghoname and Shafeek 2004;El-Desuki, et al. 2006 and Ali, et al. 2007). Also, Abd El- $\mathrm{Al}$ et al. (2005) showed that increasing of potassium sulphate up to $300 \mathrm{~kg}$./fed. resulted in the highest 
plant growth, yield and quantity of onion bulbs.

The aim of this study was to investigate the influence of natural fertilizers of phosphorus in the form of rock phosphate and potassium in the form of feldspar as well as the combination between them on growth, yield and chemical composition of onion under Ras Sudr conditions.

\section{MATERIALS AND METHODS}

The field experiments were carried out in the Experimental Farm of the Desert Research Center at Ras Sudr, South Sinai Governorate , during the growing seasons of 2006/2007 and 2007/2008 to study the response of onion plants to natural phosphorus and potassium fertilizes on growth, yield and its components, as well as chemical composition of onion (Allium cepa, L. ) cv. Giza 20. The physical and chemical analysis of the experimental soil, and the analysis of irrigation water are presented in Tables (A, B and C) according to the methods of Chapman and Pratt (1978).

Drip irrigation system was used from a well where salinity was about $3700 \mathrm{ppm}$. Seeds of onion were sown in the nursery on September 13 and 20 in both seasons, respectively.

Uniform 60-day old transplants were set up in the field $20 \mathrm{~cm}$ apart on both sides of irrigation lines. Each line was considered as an experimental plot having an area of $10.5 \mathrm{~m}^{2},(50 \mathrm{~cm}$ apart and 21 m length).

Sixteen treatments were investigated, namely the control i,e. recommended dose of NPK; $60 \mathrm{~N}$, $30 \quad \mathrm{P}_{2} \mathrm{O}_{5}$ and $48 \quad \mathrm{~K}_{2} \mathrm{O}$ units/fed. as ammonium sulphate $(20.5 \% \mathrm{~N})$, calcium super phosphate $(15$ $\left.\begin{array}{lllll}\% & \mathrm{P}_{2} \mathrm{O}_{5}\end{array}\right)$ and potassium sulphate $\left(\begin{array}{lll}48 & \% & \mathrm{~K}_{2} \mathrm{O}\end{array}\right)$, three levels of rock phosphate $\left(22 \% \mathrm{P}_{2} \mathrm{O}_{5}\right)$ as natural source, $\left(0,30\right.$ and $45 \mathrm{P}_{2} \mathrm{O}_{5}$ units/ fed.), Three levels of feldspar $\left(10 \% \mathrm{P}_{2} \mathrm{O}_{5}\right)$ as natural source of potassium $\left(0,48\right.$ and 96 the $\mathrm{K}_{2} \mathrm{O}$ units/ fed.) and the combination between the levels of rock phosphate and feldspar were applied .

Rock phosphate rates and calcium super phosphate were added to the soil one month before transplanting while the quantities of feldspar rates and potassium sulphate were divided into two parts, the first was dressed one month after transplanting and the second was added one month later.

The general agricultural practices were used with onion seedlings in the nursery and in the field.

The experiment was planned in a completely randomized block design (Snedecor, 1966) with 4 replicates.

Vegetative samples of five plants were taken from each experimental plot at 19 weeks from transplanting. Data were recorded on plant height, number of leaves/ plant, plant weight, fresh and dry weight of leaves and bulb, neck and bulb diameter and bulbing ratio (neck diameter/ bulb diameter).

Yield was harvested when $50 \%$ of the plant tops bended down at the age of 24 weeks from

Table (A) : Mechanical properties of the experimental soil(2007-2008).

\begin{tabular}{|c|c|c|c|c|c|c|c|}
\hline Depth (cm) & $\begin{array}{c}\mathrm{CaCO}_{3} \\
\%\end{array}$ & $\begin{array}{c}\text { Coarse sand } \\
(1-0.5)\end{array}$ & $\begin{array}{l}\text { Fine sand } \\
(0.25-0.10)\end{array}$ & $\begin{array}{c}\text { Sotal sand } \\
(1-0.1)\end{array}$ & $\begin{array}{c}\text { Silt } \\
(0.05-0.002)\end{array}$ & $\begin{array}{c}\text { Clay } \\
<0.002) \\
\end{array}$ & Class texture \\
\hline \multicolumn{8}{|c|}{$\%$} \\
\hline $0-30$ & 56.99 & 53.68 & 27.60 & 8.05 & 81.28 & 10.79 & Sandy loam \\
\hline $30-60$ & 52.48 & 23.74 & 62.34 & 7.59 & 86.08 & 6.33 & Sandy loam \\
\hline
\end{tabular}

Table (B): Chemical properties of the experimental soil.

\begin{tabular}{|c|c|c|c|c|c|c|c|c|c|c|}
\hline \multirow{3}{*}{ 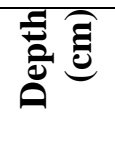 } & \multirow{3}{*}{$\frac{\pi}{2}$} & \multirow{3}{*}{ 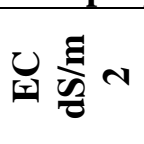 } & \multicolumn{8}{|c|}{ Saturation soluble extract } \\
\hline & & & \multicolumn{4}{|c|}{ Soluble anions (me/L) } & \multicolumn{4}{|c|}{ Soluble Cations (me/L) } \\
\hline & & & $\mathrm{CO}_{3}^{-2}$ & $\mathrm{HCO}_{3}$ & $\mathrm{SO}^{-2}{ }_{4}$ & $\mathrm{Cl}^{-}$ & $\mathrm{Ca}^{++}$ & $\mathbf{M g}^{++}$ & $\mathbf{N a}^{+}$ & $\mathbf{K}^{+}$ \\
\hline $0-30$ & 7.77 & 4.77 & 0.00 & 6.00 & 10.50 & 31.20 & 24.00 & 11.00 & 10.52 & 2.18 \\
\hline $30-60$ & 7.40 & 4.16 & 0.00 & 3.00 & 16.10 & 22.50 & 16.83 & 6.00 & 17.80 & 0.097 \\
\hline
\end{tabular}

Table (C): Chemical analysis of irrigation water.

\begin{tabular}{|c|c|c|c|c|c|c|c|c|c|}
\hline \multirow{2}{*}{ pH } & \multirow{2}{*}{$\begin{array}{c}\text { EC } \\
\text { dsm }^{-1}\end{array}$} & \multicolumn{4}{|c|}{ Soluble anions (me/L) } & \multicolumn{4}{|c|}{ Soluble Cations (me/L) } \\
\hline & & $\mathrm{CO}_{3}^{-2}$ & $\mathrm{HCO}_{3}$ & $\mathrm{SO}_{4}^{-2}$ & $\mathrm{Cl}^{-}$ & $\mathbf{C a}^{++}$ & $\mathbf{M g}^{++}$ & $\mathrm{Na}^{+}$ & $\mathbf{K}^{+}$ \\
\hline 8.60 & 7.03 & 0.00 & 2.50 & 21.23 & 41.28 & 4.50 & 13.43 & 47.05 & 0.12 \\
\hline
\end{tabular}


transplanting. Data were recorded on total yield, average fresh and dry weight of bulb, neck and bulb diameter $(\mathrm{cm})$, and bulbing ratio.

The chemical composition of bulbs were determined: total soluble solids (TSS) were measured using hand refractometer (A.O.A.C., 1975), total nitrogen and phosphorus contents were determined according to Jackson (1958) and Frie et al. (1964), respectively. While potassium and sodium contents were determined as described by Brown and Lilliland (1946), chloride content was determined by the method mentioned by Richard (1954). Also the method described by Chapman and Pratt (1978) was used for the determination of sulphur.

\section{3 . RESULTS AND DISCUSSION \\ 3.1. Vegetative growth}

Data presented in Tables 1 and 2 show the effect of natural fertilizers on plant vegetative growth expressed as plant length, number of leaves/ plant, fresh weight of whole plant, leaves and bulb, dry weight of leaves and bulb, neck and bulb diameter and bulbing ratio in both growing seasons. The results indicated that the highest and significant values of onion plant length, number of leaves/ plant, fresh weight of plant and its leaves were recorded with the control treatment (NPK mineral fertilizers) followed by feldspar treatment at the rate of $96 \mathrm{~K}_{2} \mathrm{O}$ units/fed., followed by the combination treatment (rock phosphate at $45 \mathrm{P}_{2} \mathrm{O}_{5}$ units/ fed. plus feldspar at $96 \mathrm{~K}_{2} \mathrm{O}$ units/fed).

While, fresh weight and dry matter of bulb showed the highest values with the natural fertilizer treatment $\left(96 \mathrm{~K}_{2} \mathrm{O}\right.$ plus $\left.45 \mathrm{P}_{2} \mathrm{O}_{5}\right)$ followed by the control treatment. On the other hand, the other parameters of growth were not significantly affected by the tested treatments. The results agree with those obtained by Shaheen $e t$ al. (2007) and Ali et al., (2008). This may be due to the fact that the presence of phosphorus in the soil encourages plant growth, because it is an essential nutrient (Nikolay et al, 1996; Hinsinger, 2001). Also, the enhancement of plant growth as a result of application of potassium may be due to its beneficial improvement effect on plant growth and the fundamental role of $\mathrm{K}$, which stimulates absorption and utilization efficiency from soil nutrient solution (Rizk et al. 2002; Sharma et al. 2003 and Yadav et al. 2003). Also, Moreover the addition of rock phosphate and feldspar gave the greatest plant growth because the natural fertilizers are considered as a slow release. This superiority might be attributed to that plant period has a long live period (5- 6 months), needs slow release source of nutrients during vegetative growth period (Abd El- Mouty and El- Greadly, 2008).

\subsection{Yield and its components}

Data recorded in Table (3) indicate the response of onion yield to natural fertilizers in both seasons.

The highest onion yield was significantly observed with the combination treatment of rock phosphate and feldspar at the highest rate $\left(45 \mathrm{P}_{2} \mathrm{O}_{5}\right.$ plus $96 \mathrm{~K}_{2} \mathrm{O}$ units/fed) as compared to any other treatment. The same trend was observed with fresh weight and diameter of bulb. On the other hand, the highest dry weight of bulb was significantly found with natural fertilizers (rock phosphate at $45 \mathrm{P}_{2} \mathrm{O}_{5}$ and feldspar at $96 \mathrm{~K}_{2} \mathrm{O}$ units/fed). While, the best and lowest figures of neck diameter and bulbing ratio were recorded with rock phosphate treatment at 30 and $45 \mathrm{P}_{2} \mathrm{O}_{5}$ units/fed. but the differences among all treatments were not significant in the two growing seasons. Many investigators obtained a similar trend of results (Gupta, et al. 1999; Ghoname and Shafeek , 2004 ; Abd El-Al et al. 2005). These results may be due to that phosphorus and potassium fertilizers increased the productivity of onion plant as a result of enhancement of plant growth (Tables 1 and 2). Also, yield can be affected by all physical processes including nutrient supply (Ghoname and Shafeek, 2004; El-Bassiouny, 2006 ; Ali et al. 2007). Also, phosphorus is found in plants as a constituent of nucleic acids, phospholipids, the coenzymes NAD and NADP and most important, as a constituent of ATP and other high energy compounds.

Phosphorus is essential for plant processes as photosynthesis, respiration, nitrogen and carbohydrate metabolism. The reflect of these functions improve yield of plant (Rains, 1976). Also, potassium application increases yield due to the role of potassium on production of enzyme activity and enhancement of translocation of assimilate and protein synthesis (El-Desuki et al., 2006).

\subsection{Chemical compositions}

Data presented in Table (4) revealed that TSS, total nitrogen and potassium content gave significantly the highest values with the high rate of the combination treatment of natural fertilizers (45 $\mathrm{P}_{2} \mathrm{O}_{5}$ units plus $96 \mathrm{~K}_{2} \mathrm{O}$ units/fed. ) and mineral fertilizer treatment (the control). While, the lowest and best values of sodium and chloride contents were significantly observed 
Table (1): Effect of natural fertilizers (rock phosphate and feldspar) on onion plant growth (19 weeks after transplanting) during 2006- 2007

\begin{tabular}{|c|c|c|c|c|c|c|c|c|c|c|}
\hline \multirow[t]{2}{*}{ Characters } & \multirow{2}{*}{$\begin{array}{c}\text { Pant } \\
\text { length } \\
\text { (cm) }\end{array}$} & \multirow{2}{*}{$\begin{array}{c}\text { No. of } \\
\text { leaves/ } \\
\text { plant }\end{array}$} & \multicolumn{3}{|c|}{ Fresh wt. (g.) } & \multicolumn{2}{|c|}{ Dry matter \% } & \multicolumn{2}{|c|}{ Diameter (cm) } & \multirow{2}{*}{$\begin{array}{c}\text { Bulbing } \\
\text { ratio }\end{array}$} \\
\hline & & & Whole plant & Leaves & Bulb & Leaves & Bulb & Bulb & Neck & \\
\hline Control & 71.90 & 15.00 & 157.00 & 79.00 & 78.00 & 10.50 & 10.20 & 5.50 & 2.50 & 0.45 \\
\hline $\mathrm{P}_{1}$ & 61.50 & 8.00 & 136.00 & 67.00 & 69.00 & 9.50 & 8.60 & 4.60 & 2.00 & 0.46 \\
\hline $\mathrm{P}_{2}$ & 64.80 & 8.90 & 133.00 & 73.00 & 60.00 & 10.20 & 8.90 & 4.80 & 2.20 & 0.46 \\
\hline $\mathrm{P}_{3}$ & 67.70 & 8.90 & 145.00 & 71.00 & 74.00 & 10.30 & 9.00 & 5.30 & 2.30 & 0.44 \\
\hline $\mathrm{K}_{1}$ & 69.90 & 7.80 & 127.00 & 63.00 & 64.00 & 9.80 & 8.00 & 4.50 & 2.20 & 0.49 \\
\hline $\mathrm{K}_{2}$ & 67.10 & 8.50 & 146.00 & 67.00 & 72.00 & 10.20 & 9.90 & 5.20 & 2.30 & 0.45 \\
\hline $\mathrm{K}_{3}$ & 71.70 & 9.70 & 150.00 & 78.00 & 79.00 & 10.40 & 10.80 & 5.80 & 260 & 0.43 \\
\hline $\mathrm{P}_{1}+\mathrm{K}_{1}$ & 54.00 & 7.70 & 111.00 & 53.00 & 58.00 & 9.30 & 7.00 & 3.80 & 1.90 & 0.50 \\
\hline $\mathrm{P}_{2}+\mathrm{K}_{1}$ & 56.90 & 7.90 & 119.00 & 59.00 & 60.00 & 9.40 & 7.80 & 4.20 & 2.00 & 0.48 \\
\hline $\mathrm{P}_{3}+\mathrm{K}_{1}$ & 58.80 & 8.30 & 128.00 & 66.00 & 62.00 & 10.00 & 8.20 & 4.60 & 2.10 & 0.46 \\
\hline $\mathrm{P}_{1}+\mathrm{K}_{2}$ & 59.40 & 8.00 & 126.00 & 66.00 & 60.00 & 9.50 & 8.00 & 4.40 & 2.00 & 0.45 \\
\hline $\mathrm{P}_{2}+\mathrm{K}_{2}$ & 6090 & 8.80 & 131.00 & 61.00 & 70.00 & 9.70 & 8.60 & 4.70 & 22.20 & 0.44 \\
\hline $\mathrm{P}_{3}+\mathrm{K}_{2}$ & 62.70 & 9.00 & 139.00 & 64.00 & 75.00 & 10.30 & 9.80 & 5.00 & 2.30 & 0.43 \\
\hline $\mathrm{P}_{1}+\mathrm{K}_{3}$ & 62.20 & 8.20 & 135.00 & 65.00 & 70.00 & 10.00 & 9.00 & 5.20 & 2.20 & 0.44 \\
\hline $\mathrm{P}_{2}+\mathrm{K}_{3}$ & 64.90 & 9.00 & 140.00 & 64.00 & 76.00 & 10.30 & 9.30 & 5.40 & 240 & 0.43 \\
\hline $\mathrm{P}_{3}+\mathrm{K}_{3}$ & 68.80 & 9.50 & 150.00 & 70.00 & 80.00 & 10.90 & 10.30 & 5.50 & 2.60 & 0.41 \\
\hline L.S.D.at 5\% & 10.11 & 2.60 & 13.23 & 11.55 & 13.71 & N.S & 1.39 & N.S & N.S & N.S \\
\hline
\end{tabular}

Control = NPK minerals $\left(60 \mathrm{~N}+30 \mathrm{P}_{2} \mathrm{O}_{5}+48 \mathrm{~K}_{2} \mathrm{O}\right.$ units/fed. respectively, $\mathrm{P}_{1}, \mathrm{P}_{2}$ and $\mathrm{P}_{3}=0,30$ and $45 \mathrm{P}_{2} \mathrm{O}_{5}$ units/fed. rock phosphate respectively $\mathrm{K}_{1}, \mathrm{~K}_{2}$ and $\mathrm{K}_{3}=0,48$ and $96 \mathrm{~K}_{2} \mathrm{O}$ units/fed. feldspar. 
Table (2): Effect of natural fertilizers (rock phosphate and feldspar) on onion plant growth (19 weeks after transplanting) during $2007-2008$ seasons.

\begin{tabular}{|c|c|c|c|c|c|c|c|c|c|c|}
\hline \multirow[t]{2}{*}{ Characters } & \multirow{2}{*}{$\begin{array}{c}\text { Pant } \\
\text { length } \\
\text { (cm) }\end{array}$} & \multirow{2}{*}{$\begin{array}{c}\text { No. of } \\
\text { leaves/ } \\
\text { plant }\end{array}$} & \multicolumn{3}{|c|}{ Fresh wt. (g.) } & \multicolumn{2}{|c|}{ Dry matter } & \multicolumn{2}{|c|}{ Diameter (cm) } & \multirow[t]{2}{*}{ Bulbing ratio } \\
\hline & & & Whole plant & Leaves & Bulb & Leaves & Bulb & Bulb & Neck & \\
\hline Control & 64.80 & 9.00 & 143.00 & 72.00 & 71.00 & 9.60 & 9.90 & 4.80 & 2.20 & 0.42 \\
\hline $\mathrm{P}_{1}$ & 56.00 & 7.40 & 117.00 & 54.00 & 63.00 & 8.50 & 8.20 & 4.00 & 2.00 & 0.43 \\
\hline $\mathrm{P}_{2}$ & 59.00 & 8.00 & 121.00 & 66.00 & 55.00 & 9.00 & 8.20 & 4.20 & 2.20 & 0.42 \\
\hline $\mathrm{P}_{3}$ & 61.50 & 8.20 & 132.00 & 64.00 & 68.00 & 9.50 & 8.30 & 4.50 & 2.50 & 0.41 \\
\hline $\mathrm{K}_{1}$ & 56.300 & 7.40 & 115.00 & 56.00 & 59.00 & 8.70 & 7.40 & 3.60 & 2.00 & 0.44 \\
\hline $\mathrm{K}_{2}$ & 61.00 & 8.80 & 136.00 & 68.00 & 66.00 & 8.90 & 9.00 & 4.00 & 2.10 & 0.41 \\
\hline $\mathrm{K}_{3}$ & 65.00 & 9.20 & 140.00 & 70.00 & 72.00 & 9.60 & 9.80 & 5.00 & 2.30 & 0.40 \\
\hline $\mathrm{P}_{1}+\mathrm{K}_{1}$ & 49.00 & 6.90 & 102.00 & 48.00 & 54.00 & 8.10 & 7.40 & 3.10 & 1.80 & 0.46 \\
\hline $\mathrm{P}_{2}+\mathrm{K}_{1}$ & 51.80 & 7.30 & 109.00 & 54.00 & 55.00 & 8.30 & 7.50 & 3.50 & 2.00 & 0.43 \\
\hline $\mathrm{P}_{3}+\mathrm{K}_{1}$ & 53.30 & 7.60 & 114.00 & 55.00 & 59.00 & 9.00 & 7.80 & 3.90 & 2.10 & 0.41 \\
\hline $\mathrm{P}_{1}+\mathrm{K}_{2}$ & 54.00 & 7.10 & 113.00 & 59.00 & 54.00 & 8.50 & 7.50 & 3.60 & 1.90 & 0.43 \\
\hline $\mathrm{P}_{2}+\mathrm{K}_{2}$ & 55.40 & 7.50 & 119.00 & 56.00 & 53.00 & 8.80 & 7.80 & 3.90 & 2.00 & 0.42 \\
\hline $\mathrm{P}_{3}+\mathrm{K}_{2}$ & 57.00 & 8.00 & 126.00 & 57.00 & 69.00 & 9.30 & 9.00 & 4.40 & 2.20 & 0.40 \\
\hline $\mathrm{P}_{1}+\mathrm{K}_{3}$ & 56.50 & 7.20 & 122.00 & 58.00 & 64.00 & 9.10 & 8.30 & 4.00 & 2.00 & 0.41 \\
\hline $\mathrm{P}_{2}+\mathrm{K}_{3}$ & 59.00 & 7.80 & 128.00 & 59.00 & 69.00 & 9.50 & 8.50 & 4.20 & 2.20 & 0.40 \\
\hline $\mathrm{P}_{3}+\mathrm{K}_{3}$ & 62.50 & 9.00 & 136.00 & 64.00 & 72.00 & 9.80 & 10.07 & 4.90 & 2.30 & 0.39 \\
\hline L.S.D.at $5 \%$ & 6.0 & 1.4 & 16.89 & 10.60 & 12.74 & N.S. & 1.31 & N.S. & N.S. & N.S. \\
\hline
\end{tabular}

Control = NPK minerals $\left(60 \mathrm{~N}+30 \mathrm{P}_{2} \mathrm{O}_{5}+48 \mathrm{~K}_{2} \mathrm{O}\right.$ units/fed. respectively, $\mathrm{P}_{1}, \mathrm{P}_{2}$ and $\mathrm{P}_{3}=0,30$ and $45 \mathrm{P}_{2} \mathrm{O}_{5}$ units/fed. rock phosphate respectively - $\mathrm{K}_{1}$, $\mathrm{K}_{2}$ and $\mathrm{K}_{3}=0,48$ and $96 \mathrm{~K}_{2} \mathrm{O}$ units/fed. feldspar. 
Table (3): Effect of natural fertilizers (rock phosphate and feldspar) on onion yield during 2006- 2007 and 2007- 2008 seasons.

\begin{tabular}{|c|c|c|c|c|c|c|c|c|c|c|c|c|}
\hline \multirow[b]{3}{*}{ Treatments } & \multirow[t]{2}{*}{$\begin{array}{c}\text { Yield (ton/ } \\
\text { fed.) }\end{array}$} & \multirow[t]{2}{*}{$\begin{array}{c}\text { Fresh wt. of } \\
\text { bulb (g.) }\end{array}$} & \multirow[t]{2}{*}{$\begin{array}{l}\text { Dry wt. of } \\
\text { bulb (g.) }\end{array}$} & \multicolumn{2}{|c|}{$\begin{array}{c}\text { Diameter } \\
\text { (cm) }\end{array}$} & \multirow[t]{2}{*}{$\begin{array}{c}\text { Bulbing } \\
\text { ratio }\end{array}$} & \multirow[t]{2}{*}{$\begin{array}{c}\text { Yield (ton/ } \\
\text { fed.) }\end{array}$} & \multirow[t]{2}{*}{$\begin{array}{c}\text { Fresh wt. of } \\
\text { bulb (g.) }\end{array}$} & \multirow[t]{2}{*}{$\begin{array}{l}\text { Dry wt. of } \\
\text { bulb (g.) }\end{array}$} & \multicolumn{2}{|c|}{$\begin{array}{c}\text { Diameter } \\
\text { (cm) }\end{array}$} & \multirow[t]{2}{*}{$\begin{array}{c}\text { Bulbing } \\
\text { ratio }\end{array}$} \\
\hline & & & & Bulb & Neck & & & & & Bulb & Neck & \\
\hline & \multicolumn{6}{|c|}{ First Season } & \multicolumn{6}{|c|}{ Second Season } \\
\hline Control & 10.22 & 159.70 & 23.00 & 8.30 & 2.50 & 0.34 & 9.54 & 149.10 & 22.00 & 7.50 & 2.00 & 0.27 \\
\hline $\mathrm{P}_{1}$ & 8.29 & 129.60 & 21.10 & 6.90 & 1.65 & 0.24 & 7.78 & 121.50 & 20.80 & 6.30 & 1.15 & 0.18 \\
\hline $\mathrm{P}_{2}$ & 8.6 & 134.70 & 28.20 & 7.20 & 1.70 & 0.24 & 8.52 & 128.00 & 26.50 & 6.50 & 1.20 & 0.19 \\
\hline $\mathrm{P}_{3}$ & 8.86 & 138.50 & 30.30 & 7.40 & 2.15 & 0.29 & 8.42 & 131.50 & 29.80 & 6.70 & 1.65 & 0.24 \\
\hline $\mathrm{K}_{1}$ & 7.88 & 138.10 & 22.10 & 6.60 & 1.85 & 0.28 & 7.12 & 111.20 & 21.40 & 6.20 & 1.35 & 0.22 \\
\hline $\mathrm{K}_{2}$ & 9.01 & 140.70 & 26.90 & 6.80 & 2.00 & 0.29 & 8.51 & 132.90 & 25.50 & 6.80 & 1.50 & 0.22 \\
\hline $\mathrm{K}_{3}$ & 9.45 & 147.60 & 31.37 & 8.00 & 2.05 & 0.26 & 9.31 & 145.50 & 30.40 & 7.30 & 1.55 & 0.21 \\
\hline $\mathrm{P}_{1}+\mathrm{K}_{1}$ & 8.28 & 123.30 & 14.20 & 7.20 & 1.93 & 0.28 & 7.57 & 118.30 & 11.60 & 6.50 & 1.45 & 0.24 \\
\hline $\mathrm{P}_{2}+\mathrm{K}_{1}$ & 8.99 & 140.50 & 21.70 & 7.40 & 2.10 & 0.27 & 8.35 & 130.50 & 18.60 & 6.70 & 1.60 & 0.23 \\
\hline $\mathrm{P}_{3}+\mathrm{K}_{1}$ & 10.04 & 156.90 & 27.43 & 7.60 & 2.15 & 0.27 & 9.59 & 149.60 & 25.90 & 6.90 & 1.65 & 0.22 \\
\hline $\mathrm{P}_{1}+\mathrm{K}_{2}$ & 7.72 & 120.60 & 19.10 & 7.00 & 1.90 & 0.27 & 7.08 & 110.60 & 15.60 & 6.90 & 1.40 & 0.23 \\
\hline $\mathrm{P}_{2}+\mathrm{K}_{2}$ & 8.25 & 128.90 & 21.90 & 7.80 & 2.15 & 0.28 & 7.55 & 117.90 & 18.00 & 7.20 & 1.65 & 0.22 \\
\hline $\mathrm{P}_{3}+\mathrm{K}_{2}$ & 8.88 & 137.70 & 26.90 & 8.10 & 2.20 & 0.27 & 8.54 & 133.40 & 23.40 & 7.40 & 1.70 & 0.22 \\
\hline $\mathrm{P}_{1}+\mathrm{K}_{3}$ & 10.56 & 165.00 & 15.47 & 8.40 & 2.15 & 0.28 & 9.63 & 150.50 & 12.30 & 7.60 & 1.65 & 0.24 \\
\hline $\mathrm{P}_{2}+\mathrm{K}_{3}$ & 10.64 & 165.80 & 19.30 & 8.70 & 2.25 & 0.27 & 9.67 & 151.10 & 17.00 & 7.90 & 1.75 & 0.23 \\
\hline $\mathrm{P}_{3}+\mathrm{K}_{3}$ & 11.47 & 179.20 & 23.00 & 9.10 & 2.35 & 0.26 & 10.57 & 165.20 & 21.00 & 8.30 & 1.85 & 0.22 \\
\hline L.S.D. at $5 \%$ & 0.44 & 14.00 & 5.08 & 1.43 & N.S & N.S. & 0.42 & 14.55 & 3.73 & N.S. & N.S. & N.S. \\
\hline
\end{tabular}

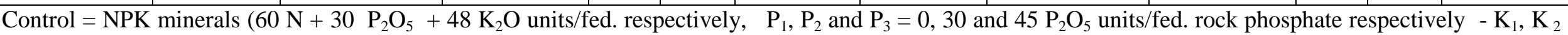
and $\mathrm{K}_{3}=0,48$ and $96 \mathrm{~K}_{2} \mathrm{O}$ units/fed. feldspar. 
Table (4): Effect of natural fertilizers (rock phosphate and feldspar) on constituents of onion chemical composition (24 weeks after transplanting) during 2006- 2007 and 2007- 2008 seasons.

\begin{tabular}{|c|c|c|c|c|c|c|c|c|c|c|c|c|c|c|}
\hline \multirow{2}{*}{$\begin{array}{c}\text { Constituents\% } \\
\text { Treatments }\end{array}$} & \multicolumn{7}{|c|}{ First season } & \multicolumn{7}{|c|}{ Second season } \\
\hline & T.S.S. & $\mathbf{N}$ & $\mathbf{P}$ & $\mathbf{K}$ & $\mathbf{N a}$ & Cl & $\mathrm{SO}_{4}$ & T.S.S. & $\mathbf{N}$ & $\mathbf{P}$ & $\mathbf{K}$ & $\mathbf{N a}$ & Cl & $\mathrm{SO}_{4}$ \\
\hline Control & 15.00 & 2.85 & 0.65 & 2.10 & 0.97 & 0.89 & 1.76 & 13.50 & 2.54 & 0.49 & 2.00 & 0.55 & 0.85 & 1.34 \\
\hline $\mathrm{P}_{1}$ & 13.50 & 2.33 & 0.58 & 1.98 & 0.58 & 0.89 & 1.38 & 12.20 & 2.15 & 0.36 & 1.73 & 0.56 & 0.86 & 1.15 \\
\hline $\mathrm{P}_{2}$ & 14.20 & 2.40 & 0.60 & 1.99 & 0.52 & 0.80 & 1.06 & 12.80 & 2.25 & 0.42 & 1.75 & 0.51 & 0.79 & 1.20 \\
\hline $\mathrm{P}_{3}$ & 14.80 & 2.71 & 0.62 & 2.03 & 0.55 & 0.85 & 1.51 & 13.07 & 2.44 & 0.45 & 1.83 & 0.54 & 0.83 & 1.28 \\
\hline $\mathrm{K}_{1}$ & 13.30 & 2.15 & 0.57 & 1.97 & 0.62 & 0.96 & 1.37 & 12.10 & 1.93 & 0.47 & 1.70 & 0.55 & 0.89 & 1.11 \\
\hline $\mathrm{K}_{2}$ & 14.00 & 2.78 & 0.62 & 2.11 & 0.57 & 0.88 & 1.40 & 12.60 & 2.23 & 0.48 & 1.90 & 0.56 & 0.86 & 1.18 \\
\hline $\mathrm{K}_{3}$ & 14.60 & 2.84 & 0.64 & 2.16 & 0.45 & 0.69 & 1.69 & 13.20 & 2.40 & 0.49 & 2.01 & 0.46 & 0.70 & 1.25 \\
\hline $\mathrm{P}_{1}+\mathrm{K}_{1}$ & 12.20 & 1.80 & 0.54 & 1.93 & 0.50 & 0.77 & 1.16 & 11.10 & 1.78 & 0.34 & 1.70 & 0.49 & 0.76 & 1.01 \\
\hline $\mathrm{P}_{2}+\mathrm{K}_{1}$ & 12.50 & 2.00 & 0.55 & 1.98 & 0.51 & 0.79 & 1.19 & 11.40 & 2.25 & 0.38 & 1.78 & 0.51 & 0.79 & 1.08 \\
\hline $\mathrm{P}_{3}+\mathrm{K}_{1}$ & 13.00 & 2.10 & 0.56 & 1.98 & 0.45 & 0.69 & 1.26 & 11.80 & 2.43 & 0.43 & 1.80 & 0.46 & 0.70 & 1.12 \\
\hline $\mathrm{P}_{1}+\mathrm{K}_{2}$ & 12.40 & 2.25 & 0.56 & 2.01 & 0.46 & 0.69 & 1.34 & 11.30 & 2.02 & 0.35 & 1.84 & 0.44 & 0.75 & 1.15 \\
\hline $\mathrm{P}_{2}+\mathrm{K}_{2}$ & 13.60 & 2.30 & 0.60 & 2.03 & 0.42 & 0.65 & 1.46 & 11.90 & 2.16 & 0.39 & 1.86 & 0.43 & 0.66 & 1.19 \\
\hline $\mathrm{P}_{3}+\mathrm{K}_{2}$ & 14.00 & 2.66 & 0.61 & 2.09 & 0.37 & 0.57 & 1.50 & 12.50 & 2.18 & 0.44 & 1.90 & 0.38 & 0.58 & 1.23 \\
\hline $\mathrm{P}_{1}+\mathrm{K}_{3}$ & 13.70 & 2.45 & 0.60 & 2.04 & 0.46 & 0.70 & 1.44 & 12.30 & 2.20 & 0.37 & 1.87 & 0.5 & 0.6 & 1.16 \\
\hline $\mathrm{P}_{2}+\mathrm{K}_{3}$ & 14.80 & 2.48 & 0.65 & 2.08 & 0.42 & 0.65 & 1.61 & 13.40 & 2.31 & 0.40 & 2.00 & 0.43 & 0.66 & 1.22 \\
\hline $\mathrm{P}_{3}+\mathrm{K}_{3}$ & 15.30 & 2.83 & 0.70 & 2.16 & 0.42 & 0.69 & 1.70 & 13.90 & 2.42 & 0.48 & 2.02 & 0.40 & 0.68 & 1.30 \\
\hline L.S.D. at $5 \%$ & 1.12 & 0.27 & N.S. & 0.14 & 0.10 & 0.09 & 0.28 & 1.16 & 0.24 & N.S. & 0.12 & 0.10 & 0.09 & N.S. \\
\hline
\end{tabular}

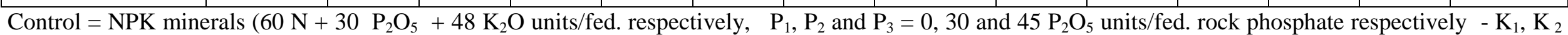
and $\mathrm{K}_{3}=0,48$ and $96 \mathrm{~K}_{2} \mathrm{O}$ units/fed. feldspar. 
with the combination treatment of rock phosphate at $45 \mathrm{P}_{2} \mathrm{O}_{5}$ plus feldspar at 48 units $\mathrm{K}_{2} \mathrm{O}$. These results were true in both growing seasons. But sulphur content in onion bulb increased with mineral fertilizer treatment and the combination treatment of natural fertilizer $\left(45 \mathrm{P}_{2} \mathrm{O}_{5}\right.$ units plus $96 \mathrm{~K}_{2} \mathrm{O}$ units/fed.). However, the differences were not significant in the second season.

The results agree with those obtained by Almadini et al., (2000), Alkaff et al., (2002), Sharma et al., (2003) and El-Desuki et al.,(2006). These results might be attributed to the increasing level of phosphorus in rooting zone which caused an increase in its absorption by plants, consequently increased the ability of plant roots to uptake more elements in plant tissues. Also, increasing $\mathrm{K}$ application in the soil may increase its absorption (Ali et al, 2001; Singh and Verma, 2001).

\section{Conclusion}

The addition of natural fertilizers ( rock phosphate and feldspar) at the rates of $45 \mathrm{P}_{2} \mathrm{O}_{5}$ and $96 \mathrm{~K}_{2} \mathrm{O}$ units/fed improved growth, yield and chemical composition of plant as mineral fertilizers. The natural fertilizers reduce contamination which is caused by chemical fertilizers and produce healthy and safe plants, as well as the fact that natural fertilizers have less cost than chemical fertilizers.

\section{REFERENCES}

Abd El-Al F.S., Shafeek M.R., Ahmed A.A.l and Shaheen A.M. (2005). Response of growth and yield of onion plants to potassium fertilizer and humic acid. J. Agric., Sci., MansouraUniv., 30 (10): 315- 326.

Abd El- Mouty M. and El-Greadly Nadia H. M. (2008). The productivity of two Okra cultivars as affected by gibberellic acid, organic $\mathrm{N}$, rock phosphate and feldspar application. J. of App. Sic. Res., 4 (6): 627-636.

Ali A.H. and Taalab Ali A.H. and Taalab A.S. (2008). Effect of natural and/ or chemical potassium fertilizer on growth, bulbs yield and some physical and chemical constituents of onion (Allium cepa, L. ). Res. J. of Agric. and Biolog. Sci., 4 (3):

Ali A.H., Rizk A. F., Shaheen A.M. and AbdelMouty M. M. (2007). Onion plant growth, bulbs yield and its physical and chemical properties as affected by organic and natural fertilization. Res. J. Agric. \& Biol. Sci., 3 (5): 380- 388.

Ali A.H., Abdel- Mouty M.M. and Shaheen A.M. (2001). Effect bio- nitrogen, organic and inorganic fertilizer, on the productivity of garlic (Allium sativum, L.) plants, Egypt., J. Appl. Sci., 16 (3): 173- 188.

Alkaff H.A., Saeed O.S. and Salm A.Z. (2002). Effect of bio- fertilizer inorganic, organic and foliar application of power 4 on the productivity of onion. Univ. Aden. J. Natua. and Appl. Sci. Univ. of Aden. Yemen, 6 (1): 1-14.

Almadini A.M., Al-Thabt S.S. and Hamail A.F. (2000). Effect of different application rates of two compound fertilizers on growth, yield and yields mineral composition of onion (Allium cepa, L. ) Egypt. J. Appl. Sci., 15 (10) 134- 142.

A.O.A.C. (1975). "Official Methods of analysis of the Association of official Ana. lytical chemists. Twelfth Ed. Published by the Assocation of Official Analytical chemistis. Wasington D.C.

Brown J.D. and Lillaland O.(1946). Rapid determination of potassium and sodium in plant material and soil extracts by flame photometry. Amer.Soc.Hort.Sci.,38:341364.

Chapman H.D. and Pratt P.F. (1978). Methods of analysis for soils, plants and water. Univ. California, Div. Agric. Sci., 4034.

El-Bassiouny A.M. (2006). Effect of potassium fertilization on growth, yield and quality of onion plants. J. Appl., Sci. Res., 2 (10): 780-785.

El-Desuki M., Abdel - Mouty M.M. and Aisha H.A. (2006): Response of onion plants to additional dose of potassium application. J. Appl. Sci. Res., 2 (9): 592- 597.

Abd El- Al F.S., Shaheen A. M., Riz. F. A.and Hafez. M.Magda (2010). Influence of irrigation intervals and potassium fertilization on productivity and quality of onion plant. International Journal of Academic Research 2(1):110-116.

Frie E., Peyer K. and Schultz E.(1964). Determination of phosphorus by ascorbic acid. Schw. Land Wirt Schaft for Shung. Heft, $3: 318-328$.

Ghoname A.A. and Shafeek M. R. (2004). Growth and productivity of sweet peper (Capsicum annum, L.) grown in plastic house as affected by organic, mineral and 
bio- N- fertilizer . Pakistan J. Agron., 4 (4): 369- 372.

Gupta R.P., Sharma V.P., Singh D.K. and Srivastava K.J. (1999). Effect of organic manures and inorganic fertilizers on growth, yield and quality of onion yield and quality of onion variety Agrifound Dark Red. News Letter, National Hort. Res. and Deve. Foundation, 19 (2/3): 711.

Hinsinger P. (2001). Bioavailability of soil inorganic $\mathrm{P}$ in the rhizopshere as affected by root- induced chemical changes: a review. Plant and soil, 237 (2): 173- 195.

Jackson M.L. (1958). Soil chemical analysis. Prentice-Hall Inc., Englewood Cliffs, N.J., U.S.A.

Marschner H. (1995). Mineral nutrition of higher plants. Academic Pess. London, Pp. 889.

Nikolay Vassilev France I., Vassileva M. and Azcon R. (1996). Improved plant growth with rock phosphate solubilized by Aspergillus niger on sugar beet. West Estacion Expeimental del- Zaidin, CSIC Prof. Albareda, 1, 8008, Granada, Spain.

Pant H.K. and Reddy K.R. (2003). Potential internal leading of phosphorus in a wetlands constructed in agricultural land. Water Research, 37 : 965- 972.

Rains D.W. (1976). Mineral metabolism. In J. Boner and J. E. Varner, eds., Plant Bioch. New York, Acad, Press.

Richards L.F. (1954). Diagnosis and improvement of saline and alkaline soils. Agric. Hand Book, USA (60).

Rizk F. A. (2001). Effect of slow release of nitrogen fertilizer on growth and yield of patato plants. J. Agric., Sci., Mansoura Univ., 26 (9): 5671- 5686.

Rizk F.A., Foly H. M. and Adam A. S. (2002). Response of onion plant (Allium cepa, L.) 10 organic and inorganic nitrogen fertilizers. Minia. J. of Agric. Res. Develop., 22: 129- 149.

Shaheen A.M., Abd El-Mouty M. M., Ali A. H. and Rizk F. A. (2007). Natural and chemical phosphrus fertilizers as affectel Onion plant Growth, Bulls yield and its some physical and chemical properties. Asut. J. of Basic and App. Sci. 1 (4): 519524.

Sharma R.P., Datt N. and Sharma O.K. (2003). Combined application of nitrogen, phosphorus, potassium and farmyard manure in onion (Allium cepa, L.) on high hills, dry temperature condition of NorthWest Himalyagas. Indian, Agric. Sci., 73: 225-227.

Singh S.P. and Verma A.B. (2001). Response of onion (Allium cepa, L.) to potassium application . Indian J. of Agric., 46 : 182185.

Snedecor G.W. (1966). Statistical methods. The Iowa State Univ. Pres Ames. Iowa, USA, $5^{\text {th }}$ ed., $534 \mathrm{p}$.

Straaten P.V. (2002). Rocks for crops, ICRAF. Nairobi, Kenya, P. 338.

Yadav R.L., Son N.L. and Yadav B.L. (2003). Response of onion to nitrogen and potassium fertilization under semi- arid condition of Rajasthan. Indian. J. Hort., 60 (2): 176-178. 228-237. 


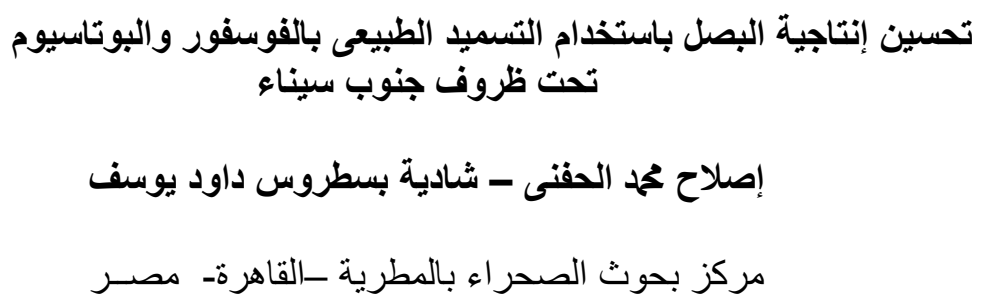

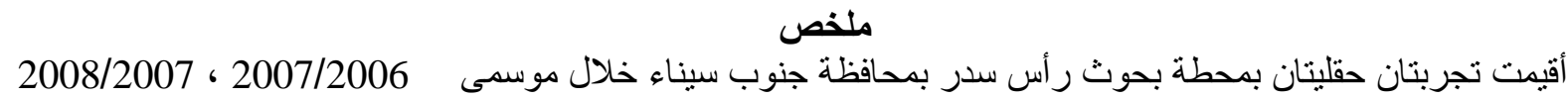

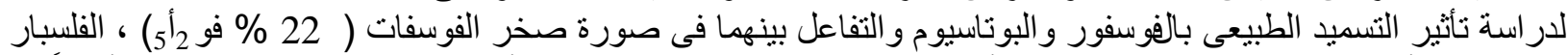

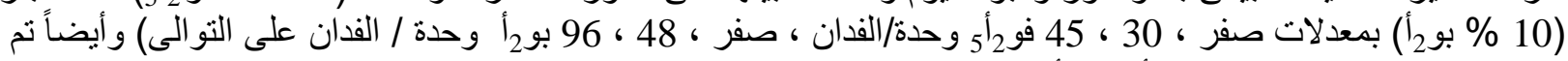

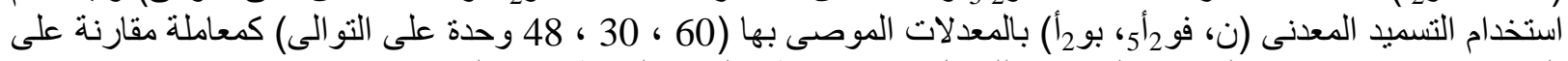

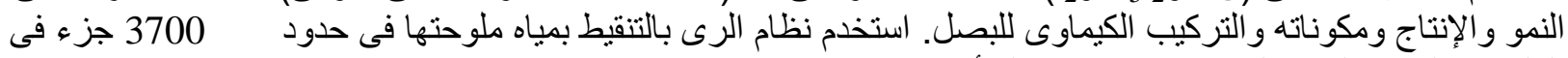

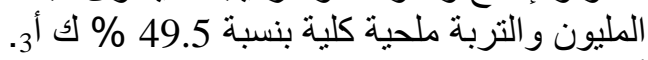

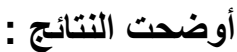

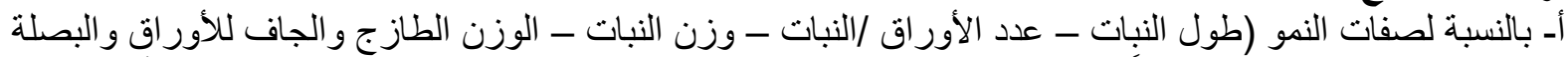

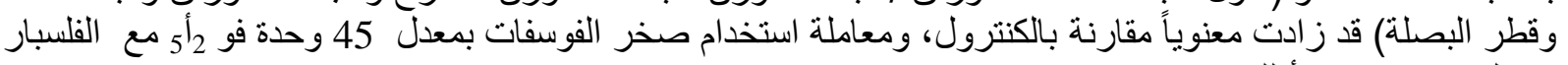
بمعدل 96 وحدة بورأ للفدان.

ب- بالنسبة للإنتاج فقد تفوق بولف معنوياً وأعطى أعلى قيمة عن باقى المعاملات باستخدام المعاملة السابقة بالتسميد الطبيعى من

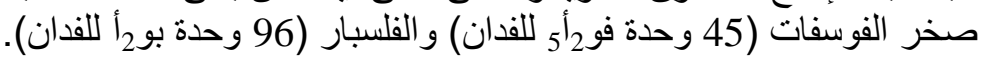

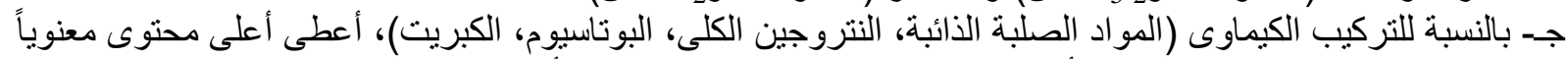

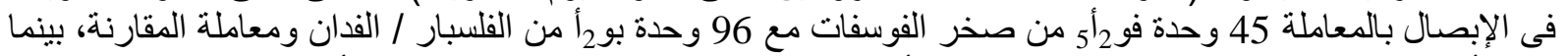

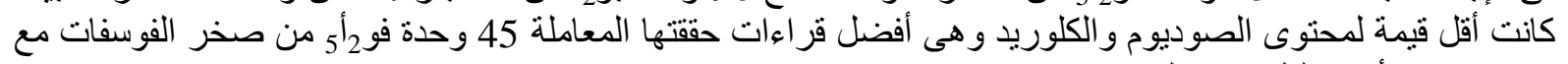
48 وحدة بورأ من الفلسبار / الفدان).

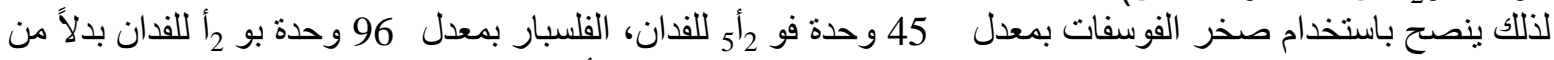

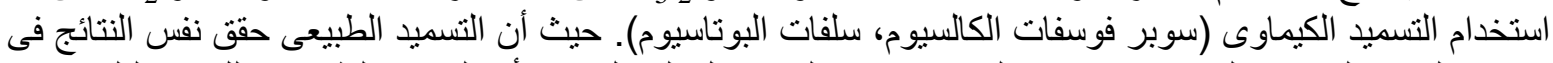

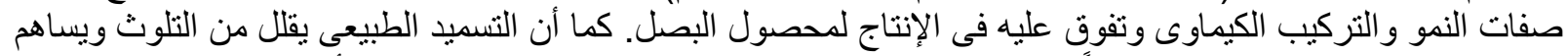

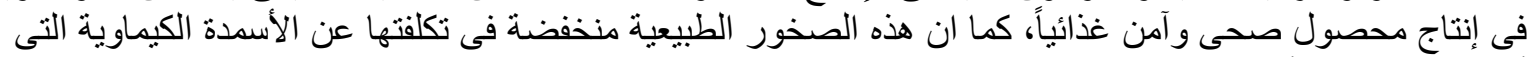
أصبحت باهظة الأسعار.

المجلة العلمية لكلية الزراعة - جامعة القاهرة - المجلد (62) العدد الاول (يناير 2011):71-80. 